\title{
"The concept of distribution of powers among accounting entities considering modernization strategy in the public sector of Ukraine"
}

\begin{tabular}{|c|c|}
\hline AUTHORS & $\begin{array}{l}\text { Nadiia Khorunzhak } \\
\text { Oleksandra Karmaza https://orcid.org/0000-0003-4895-5220 } \\
\text { Mykola Kurylo (D https://orcid.org/0000-0003-1496-134X } \\
\text { Hikmat Javadov }\end{array}$ \\
\hline ARTICLE INFO & $\begin{array}{l}\text { Nadiia Khorunzhak, Oleksandra Karmaza, Mykola Kurylo and Hikmat Javadov } \\
\text { (2018). The concept of distribution of powers among accounting entities } \\
\text { considering modernization strategy in the public sector of Ukraine. Problems and } \\
\text { Perspectives in Management, 16(1), 96-104. doi:10.21511/ppm.16(1).2018.09 }\end{array}$ \\
\hline DOI & http://dx.doi.org/10.21511/ppm.16(1).2018.09 \\
\hline RELEASED ON & Wednesday, 14 February 2018 \\
\hline RECEIVED ON & Tuesday, 02 January 2018 \\
\hline ACCEPTED ON & Thursday, 01 February 2018 \\
\hline LICENSE & $\begin{array}{l}(c)) E Y \\
\text { This work is licensed under a Creative Commons Attribution } 4.0 \text { International } \\
\text { License }\end{array}$ \\
\hline JOURNAL & "Problems and Perspectives in Management" \\
\hline ISSN PRINT & $1727-7051$ \\
\hline ISSN ONLINE & $1810-5467$ \\
\hline PUBLISHER & LLC "Consulting Publishing Company "Business Perspectives" \\
\hline FOUNDER & LLC "Consulting Publishing Company "Business Perspectives" \\
\hline
\end{tabular}

NUMBER OF REFERENCES

19

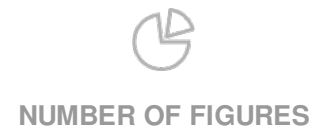

3
NUMBER OF TABLES

2

(C) The author(s) 2022. This publication is an open access article. 


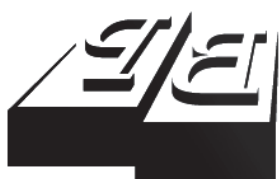

BUSINESS PERSPECTIVES

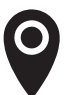

LLC "CPC "Business Perspectives" Hryhorii Skovoroda lane, 10, Sumy, 40022, Ukraine

www.businessperspectives.org

Received on: $2^{\text {nd }}$ of January, 2018 Accepted on: $1^{\text {st }}$ of February, 2018

( ) Nadiia Khorunzhak, Oleksandra Karmaza, Mykola Kurylo, Hikmat Javadov, 2018

Nadiia Khorunzhak, Doctor of Economics, Ternopil National Economic University, Ukraine

Oleksandra Karmaza, Doctor of Law, Associate Professor, Institute of Continuing Education, Taras Shevchenko National University of Kyiv, Ukraine

Mykola Kurylo, Doctor of Law, Sumy National Agrarian University, Ukraine

Hikmat Javadov, Ph. D. (Law), Researcher Koretsky Institute of State and Law of National Academy of Sciences of Ukraine, Chairman of the United Diaspora of Azerbaijanis of Ukraine, Kyiv, Ukraine

\section{(ㄷ)(1) $(9$}

This is an Open Access article, distributed under the terms of the Creative Commons Attribution-NonCommercial 4.0 International license, which permits re-use, distribution, and reproduction, provided the materials aren't used for commercial purposes and the original work is properly cited.
Nadiia Khorunzhak (Ukraine), Oleksandra Karmaza (Ukraine),

Mykola Kurylo (Ukraine), Hikmat Javadov (Ukraine)

\section{THE CONCEPT OF DISTRIBUTION OF POWERS AMONG ACCOUNTING ENTITIES CONSIDERING MODERNIZATION STRATEGY IN THE PUBLIC SECTOR OF UKRAINE}

\begin{abstract}
Reformation of accounting in the public sector of Ukraine, which was aimed at adapting to the international standard requirements, led to some inconsistencies related to the division of powers of its subjects. In this regard, it became relevant to study not only the methodology transformation, but also to optimize the powers of accounting subjects. Avoiding duplication of functions will harmonize the accounting system, simplify the mechanisms of data formation and increase the effectiveness of making managerial decisions. The application of the approaches for differentiating the powers of the subjects of accounting and the links between them will improve the quality and informational outgoing credentials, which are subsequently used in making managerial decisions. The study results can serve as the basis for developing a comprehensive information management system for public sector entities aimed at improving their performance.
\end{abstract}

Keywords

subjects of accounting, public sector, functions, powers, improvement, system management requests

\section{JEL Classification $\quad \mathrm{M} 40, \mathrm{M} 41$}

\section{INTRODUCTION}

Financial support for budgetary institutions requires maximum involvement of all possible means for achieving its efficient use. One of the most efficient instruments for this problem solution is accounting and control systems, which make economically justified reduction in costs possible due to their operational management. Accounting and control as an information base and source of such management should meet the criteria of responsiveness, availability and efficiency. The development of modern information systems and their active use for the purpose of accounting and control allows achieving these criteria with minimal resource and time expenditures. The use of modern mathematical theory and modelling for the same purpose is an integral and quite powerful tool for accounting and control improvement as management functions. Developing the theory and methodology of accounting and cost control of budgetary institutions based on these principles, focusing on the development of the subsystem of internal (management) accounting and using modern information systems in terms of increased competition are quite important research areas. In this context it is important to define carefully interconnections and components of the financial and internal business (management) ac- 
counting in budgetary institutions to prepare more detailed data for internal decision making.

The improvement of accounting system as a course of accounting modernization strategy in public sector involves the distribution of powers between the entities regarding accounting of assets, liabilities, revenues and expenses as well as the development and implementation of common national regulations (standards) of accounting and a single chart of accounts harmonized with budget classification.

\section{LITERATURE REVIEW}

Considering distribution of powers regarding accounting of assets, liabilities, revenues and expenses as one of the main courses of modernizing the accounting system in public sector indicates the imperfect construction of semantic network of organizational and documentary interconnections between accounting entities. In the national provisions (standards) of public sector accounting there is currently no clear interpretation of accounting entities (MFU, 2010). Instead, in the Foreword to International Accounting Standards for the public sector, it is noted that the term of "public sector" refers to national governments, regional authorities (e.g., states, provinces, territories), local (e.g., municipal, district (village)) authorities and the relevant public business entities (e.g., agencies, boards, commissions and enterprises) (ASPS, 2017).

Bezzubets (2012) analyzed cardinal changes in the system of the budgetary process, the grounds for implementing reforms and the benefits of the accounting system modernization.

Bergel (2010) discovered that for effective state control, high-quality work of the accounting entities and rationalization of state actions are needed. To achieve that, the concept of distribution of powers among accounting entities is vital.

Herasymenko et al. (2010) considered topical issues in the organization of accounting, and proposed new approaches to improve information support, organization of audit and control over the use of budget funds. Paliy (1975) analyzed accounting in the system of economic information.

Practical aspects in the implementing control concepts were studied by Horvath (2003). It was noticed what aspects an effective control system should contain and what is necessary to achieve this. Hutsailiuk (2013) considered the accounting control system in market conditions, conceptual approaches to reforming the accounting system in Ukraine, and paid a special attention to financial control in the management system.

Yevdokymov (2005) substantiated the expediency of introducing the universal model of the accounting system, developed the modeling technique to form the accounting policy of the enterprise and proposed the concepts of modeling in accounting.

Challenges of Ukrainian public sector and the way for implementing strategic reforms for successful Ukraine-EU cooperation were analyzed by Lysiak, Kachula and Kulichenko (2017). Makarenko (2017) more specifically studied the problems of Ukrainian public companies and found out that non-financial information disclosure is their weakest point.

No reforms in public sector could be provided without accountants' professional skills and competencies, their role in achieving sustainable development goals is crucial (Makarenko \& Plastun, 2017). Numerous publications as well as complaints of practicing accountants about the confusion and inconsistency of the current legislation in this area confirm the relevance of developing the research and, to some extent, determine their area.

\section{METHODS}

Systematic approach is the methodological basis for conducting the study. It combines empirical assumptions, logical and experimental generalizations, as well as modeling and formalizing the research findings.

The developed model solutions take into account the main directions of change of powers. Particular emphasis is placed on ensuring that such changes correspond to managerial requests and were economically feasible. 


\section{RESEARCH FINDINGS}

The coordination of powers as the area of accounting improvement is one of the important aspects of the problem, which is closely connected to the determining the structure of entities in the public sector. However, the formation of recommendations on this issue involves two dimensions. Firstly, it requires improving separation of powers between the same entities of public sector, especially in the part of administrators of budgetary funds, control and higher institutions, bodies and organizations. Secondly, (this is directly related to the object of the research) separation of powers concerning conduct of accounting of assets, liabilities, revenues and expenses directly between departments and officials of accounting services and entities financed from the budget.

However, more important is research of capabilities for improving separation of powers regarding conducting accounting of assets, liabilities, revenues and expenses directly between departments and officials of accounting services.

While developing the structure of accounting information system of budgetary institutions, it is recommended to base on the planned purpose. Structurally modernized accounting system (information system of management), which is proposed to be developed, has to include a subsystem of accounting (financial) and managerial account- ing and semantic network of powers at least embrace accounting, planning and analysis (Figure 1).

The structure (see Figure 1) can be supplemented by a number of components if necessary. Special emphasis should be made on the employees, their skills to summarize the information and the ability to present the processed data in a format suitable for quick perception. Deputy Chief Accountant is advisable to be given the power to ensure the data collection from structural divisions of accounting services and their accounting employees regarding opportunities to improve the efficient use of monetary, material and human resources (Table 1).

In fact, it is necessary to form a supplement to qualification characteristics and powers concerning all accountants and it should be based upon the knowledge of how to optimize entity's performance as well as opportunities for improving the accounting of assets, income, liabilities and expenses. The specificity and objectivism of this approach is determined by modern development of technical capacity and by the present needs of using accounting system for the optimization purposes. The powers of management accounting department employees should be associated with the formation of relevant and appropriate information for management purposes. It is also important to build a rational semantic network of interconnections between departments and officials of such information accounting system. For example,

Table 1. Recommended qualification characteristics and responsibilities of the accounting service employees

\begin{tabular}{|c|c|}
\hline $\begin{array}{c}\text { Profession } \\
\text { (position) }\end{array}$ & Qualification characteristics \\
\hline Chief accountant & $\begin{array}{l}\text { Tasks and responsibilities: (in addition to specified (CMU, 2011) and (MLSP, 2004) summarizes data to } \\
\text { optimize the use of resources and organizes the development of documentation and activities aimed at } \\
\text { achieving financial savings, materials, low value items, as well as more efficient use of assets. } \\
\text { Must know: methods and techniques of analysis, activity planning and forecasting; principles and } \\
\text { procedure of optimization models design and construction; method of internal reporting formation and } \\
\text { the needs of users in information data that can be used for optimization; principles and methods of } \\
\text { calculating the efficiency of accounting system at the stage of its modernization; innovative ways to make } \\
\text { analytical calculations based on the use of software and programming languages }\end{array}$ \\
\hline \multirow[t]{2}{*}{$\begin{array}{l}\text { Deputy chief } \\
\text { accountant }\end{array}$} & $\begin{array}{l}\text { Tasks and responsibilities: (in addition to specified (CMU, 2011) and (MLSP, 2004) is responsible for the } \\
\text { timely submission, from accounting employees to the chief accountant, of the information required to } \\
\text { form conclusions and make decisions to optimize resources use; develops and submits forms of internal } \\
\text { documentation for approval, is involved in developing algorithms for computing expected indicators; } \\
\text { forms proposals for the composition of performance indicators, makes calculations for development } \\
\text { projects (manufacturing and services); performs information processing in order to ensure the } \\
\text { achievement of financial savings, materials, low value items, fixed assets; develops proposals on ensuring } \\
\text { growth of competitiveness of entity's activity in general and product types (services) in particular. }\end{array}$ \\
\hline & $\begin{array}{l}\text { Must know: the specifics of the product; methods of research, ways to search for reserves to reduce costs } \\
\text { and increase the volume of revenues; methodology of economic and mathematical modelling; processing } \\
\text { technology of accounting information in a computer network and ways to correct mistakes; disadvantages } \\
\text { of the existing accounting system and practices and approaches to their elimination }\end{array}$ \\
\hline
\end{tabular}




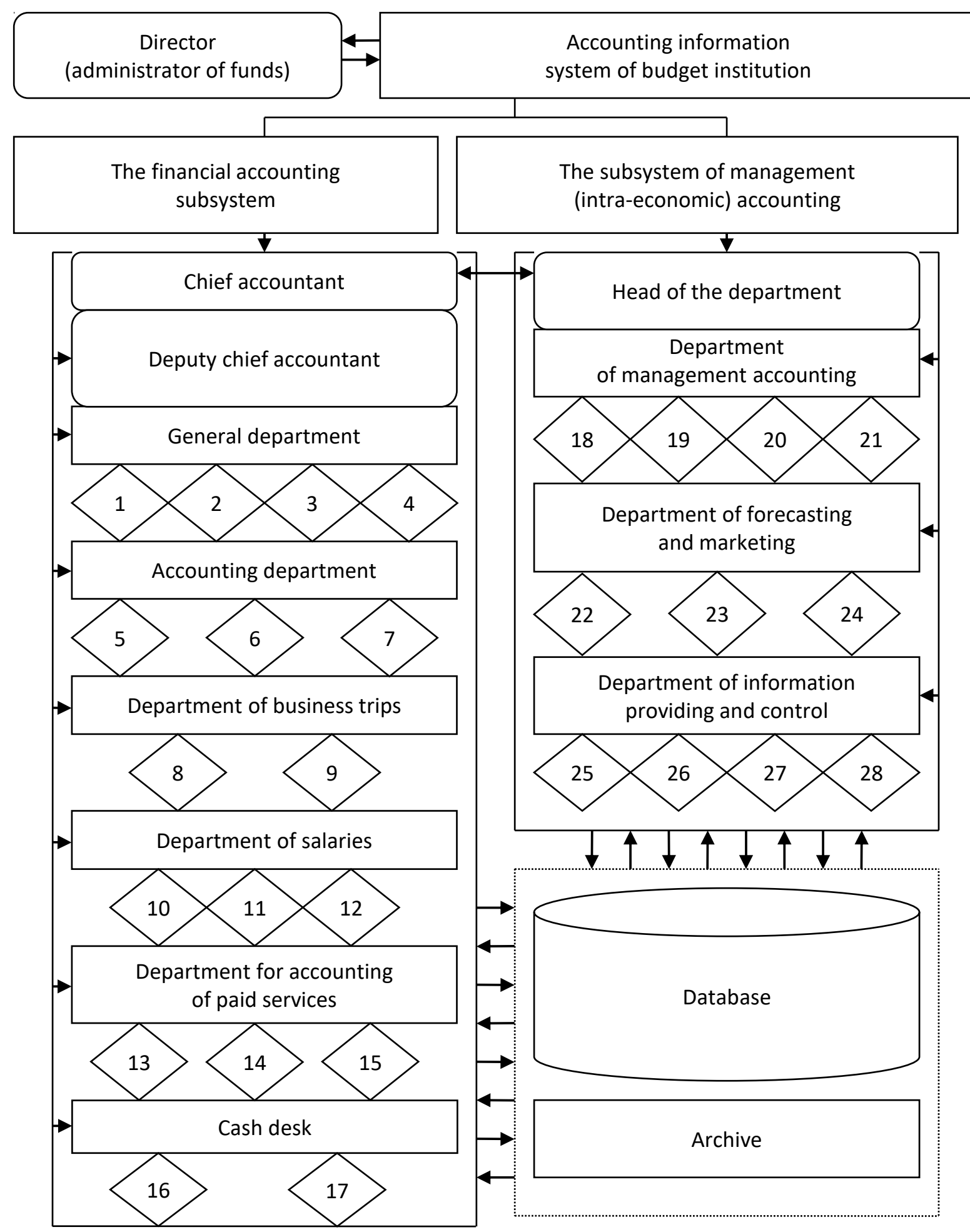

Notes: ${ }^{*}$ - a structural unit that loses its functional value due to the development of the system for electronic payments; 1 - the second deputy chief accountant; 2 - senior accountant; 3 - accountant-auditor; 4 - accountant on calculations; 5,6 - accountants on accounting materials and LVI; 7 - accountant on accounting of fixed assets and intangible assets; 8, 9 - accountant on accounting of trip expenses; 10,11,12 - accountants on labor accounting and salaries (differentiated by department); 13, 14, and 15 - accountants and controllers of payments for chargeable services; 1617 - cashiers and accountants; 18 - senior accountant and economist; 19 - 1st category economist; 20, 21 - economists on accounting of revenues and expenditures (costs); 25 deputy chief of accounting management department on the issues of information; 26 - 1st category engineer; 27 - economist and controller of the network and the performance of the functions of accounting and analysis; 28 - programming engineer.

Figure 1. The recommended structure of the accounting information system of budgetary institutions 
Table 2. Recommended qualification characteristics and duties (powers) of management accounting department employees

\begin{tabular}{|c|c|}
\hline No. & Qualification characteristics \\
\hline & Heads \\
\hline \multirow{4}{*}{1} & The head of management accounting department \\
\hline & $\begin{array}{l}\text { Tasks and responsibilities: forms structural schemes of document flows and distributes responsibilities among } \\
\text { the department employees. Supervises the management accounting aimed at optimizing activities, revenues and } \\
\text { expenditures (costs). Leads the preparation of information data and a process of projects' development of costs } \\
\text { (expenses), income and activities' optimization (including individual departments). Develops standards, regulations, } \\
\text { substantiation, documentation as well as calculations associated with the search of opportunities to improve the } \\
\text { performance. Organizes and is directly involved in preparing budgets, plans, projects, calculations, designing methods } \\
\text { and techniques of management accounting, forming algorithms of efficiency calculation, improving accounting } \\
\text { procedures. Ensures the information data, conclusions and recommendations for the management, monitors the } \\
\text { adherence to schedules of submission of accounting information to the employees of the department and other } \\
\text { concerned users through channels of internal communication. Organizes the formation of internal reporting, and } \\
\text { develops forms of documentation for management accounting. }\end{array}$ \\
\hline & $\begin{array}{l}\text { Must know: the specific features of an entity and its activities, how to apply analytical methods, ways and techniques } \\
\text { and have skills of their application; methods for evaluating the performance and projects that are being developed by } \\
\text { the department; methods of economic and mathematical modelling and peculiarities of their application as to specific } \\
\text { objects of accounting; the technology of computerized data processing and the possibility of its application and } \\
\text { improvement. }\end{array}$ \\
\hline & $\begin{array}{l}\text { Qualification requirements: University degree in relevant field of study (Master, Specialist). Job experience in } \\
\text { management accounting for at least } 2 \text { years }\end{array}$ \\
\hline \multirow{5}{*}{2} & Deputy chief of management accounting on informatization \\
\hline & $\begin{array}{l}\text { Tasks and responsibilities: organizes the work of subordinate department; develops regulations, algorithms, forms } \\
\text { of documentation and data storage. Ensures saving and distribution of information data to corresponding structural } \\
\text { departments and corresponding officials. Assesses innovative opportunities of applying modern information computer } \\
\text { technologies and forms corresponding submissions with proposals for improving the information system. Organizes } \\
\text { submission of management accounting information and its generalization in internal reporting forms. Ensures research } \\
\text { and proposes how to protect information against unauthorized access. Performs economic assessment of the benefits } \\
\text { of semantic innovative technologies in their application in the accounting system. Ensures the use of possibilities of } \\
\text { reducing labor-output ratio of accounting personnel through the widespread use of computer technology. Solves the } \\
\text { task of structural formation of information accounting data and knowledge bases. Monitors the condition of information } \\
\text { network and ensures its improvement. }\end{array}$ \\
\hline & $\begin{array}{l}\text { Generates accounting information flows into information arrays and ensures their transmission through communication } \\
\text { channels to corresponding users for monitoring and making decisions. }\end{array}$ \\
\hline & $\begin{array}{l}\text { Must know: specific nature of management needs in management accounting information, management accounting } \\
\text { methodology, technical capabilities of computer networks and modern information technology. }\end{array}$ \\
\hline & $\begin{array}{l}\text { Qualification requirements: University degree in relevant field of study (Master, Specialist in Economic Cybernetics or } \\
\text { Computer Engineering). Experience for at least } 2 \text { years }\end{array}$ \\
\hline
\end{tabular}

the head of management accounting department must be competent in Optimization projects' development (activities, production of new types of products (services) and others), know a methodology and techniques of economic and mathematical modelling, etc. (Table 2).

Distribution of powers between the departments and officials, in case of the accounting system development which is aimed at optimization using management component, requires interconnecting management process and processes of accounting. The definition of powers for accounting employees by taking into account the semantics of accounting information system is logical (Figure 2).

The focus on revenues and expenditures (costs) was the basis for the development of generalized and recommended distribution of powers (see Figure 2). However, it may happen that the need to improve the efficiency of functioning budgetary institutions will require the system of management accounting. The relationship between accounting employees and their powers (see Figure 2) can later be supplemented according to systemic management transformation of budget institutions, changing needs of senior staff in the unbiased and relevant information for making decision, and according to developing software products, new forms for presentation of accounting information sources and the development of number theory, functions of complex variables, higher algebra for improving the technical means and models of digital accounting data processing.

Such position matches the conception of management-oriented accounting. Nowadays, the development of such system is quite relevant, particularly taking its orientation into account, to provide the possibility for controlling the successful im- 


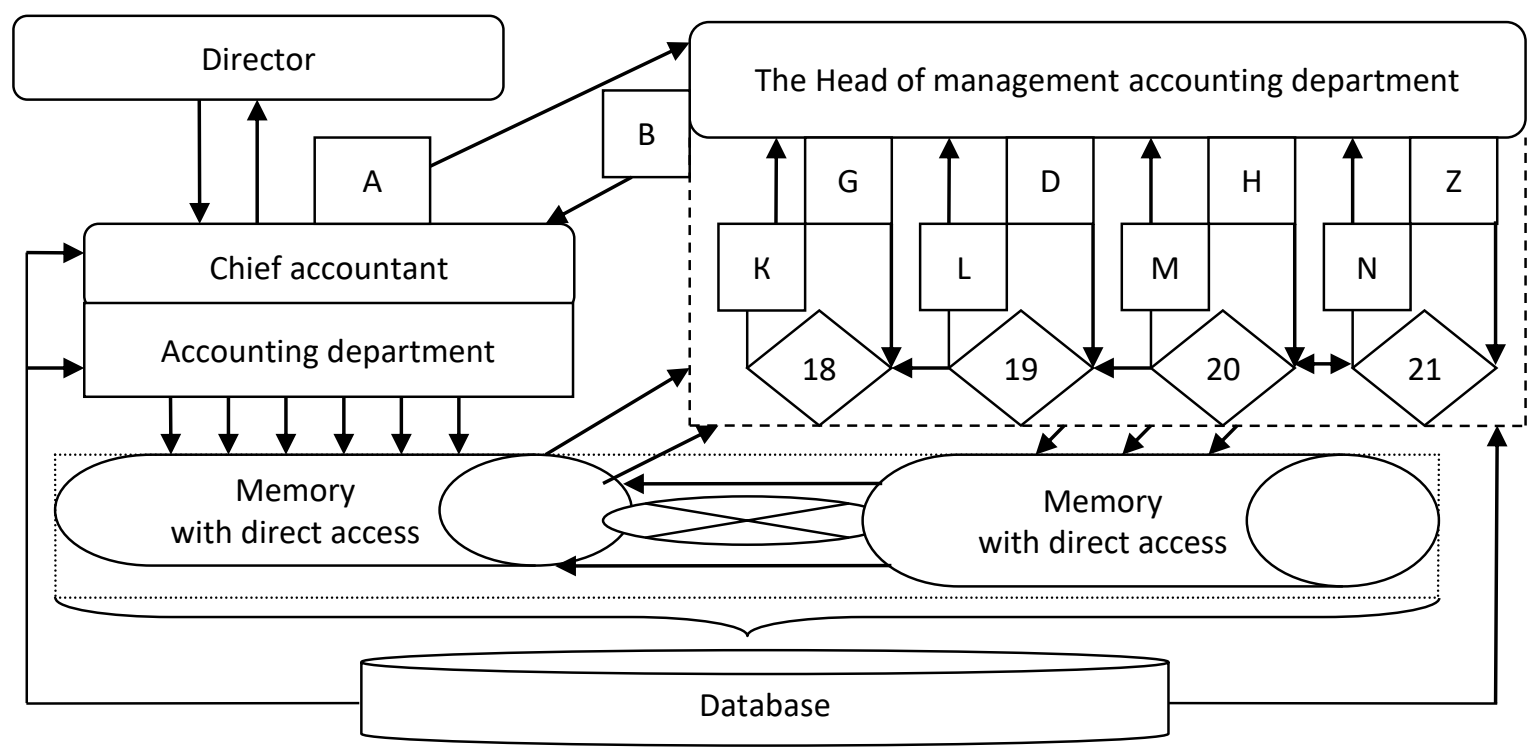

Notes: 18 - Leading Accountant-economist: G - receiving orders and instructions regarding the areas of conducting the management accounting (are developed based on the chosen development strategy); $\mathrm{K}$ - forming payments to the estimates (to optimize expenditures, research and substantiation of using more improved basic calculation indices (so called performance indicators of budget institutions and norms of expenditures for them), search and evaluation of innovative models of accounting (optimization models)); optimization of expenditure and revenue calculations; managing the development process of internal documentation forms and reporting; participation in the formation of internal reporting resource using and project of management solutions to development proposals aimed at optimizing expenditures, revenues and the activity of budget institution as a whole; 19 - the economist of the 1st category: D - forming orders or instructions regarding popular data in management system which are formed by the department; L - business plans working out to develop paid services; conducting internal operational and analytical details of accounting expenditures (analysis of deviations); forming a database about competitors (the list of services, price, volume of activity, internal benefits: employees, technologies, experience of organization activity); 20, 21 - economists on accounting of revenues and expenditures (costs): $\mathrm{H}, \mathrm{Z}$ - proving information on the accounting policies of budgetary institutions on income and expenditure (the procedure for recognition, evaluation, the need in detailing, the need for the accounting of the dynamics and absolute and relative deviations, etc.); $\mathrm{M}, \mathrm{N}$ - administrative accounting of incomes and expenditures (including analytical accounts of management accounting); analysis of revenues and expenditures; data forming on the interim results of execute expenditures and revenues (including in the form of payments of deviations); preparation of final results for the formation of internal reporting on expenditures and revenues of budgetary institutions.

Figure 2. Recommended distribution of powers and semantics of the accounting information system of budgetary institutions focused on optimization

plementation of solutions, and also the definition of univalent target indicators regarding decisions adopted. The necessity and possibility of corrective actions appear based on control of these parameters by comparing actual values and analysis of possible deviations (Jamaludin et al., 2009).

Given the objective nature of a need to develop this area of accounting, it seems appropriate not just to form a single chart of accounts in public sector of accounting (which combines the accounts for the accounting of budgets and accounts designed for the accounting of the public sector activities which public institutions belong to) but also introduce the accounts of management accounting into the structure. If faced with selecting this approach, the conditions will be created which are able to contribute to optimization of budgetary institutions' activity.
Given the fact that one of the main goals of reforms in public sector accounting system is to improve the performance, the actual task is to form, test and use indicators and criteria for evaluation of public sector entity activities, including budgetary institutions. The main purpose of management accounting is to provide users with planned, actual and predicted information about the activity of the institution and the environment for informed decision-making. The main information users in this case are top management, managers and financial services of the institutions (Naboyshchikova, 2009, p. 158-159).

It is important to analyze modular structure elements of management accounting according to the relevant elements (planning of estimate and monitoring its implementation, costs and revenues accounting; data preparation for manage- 


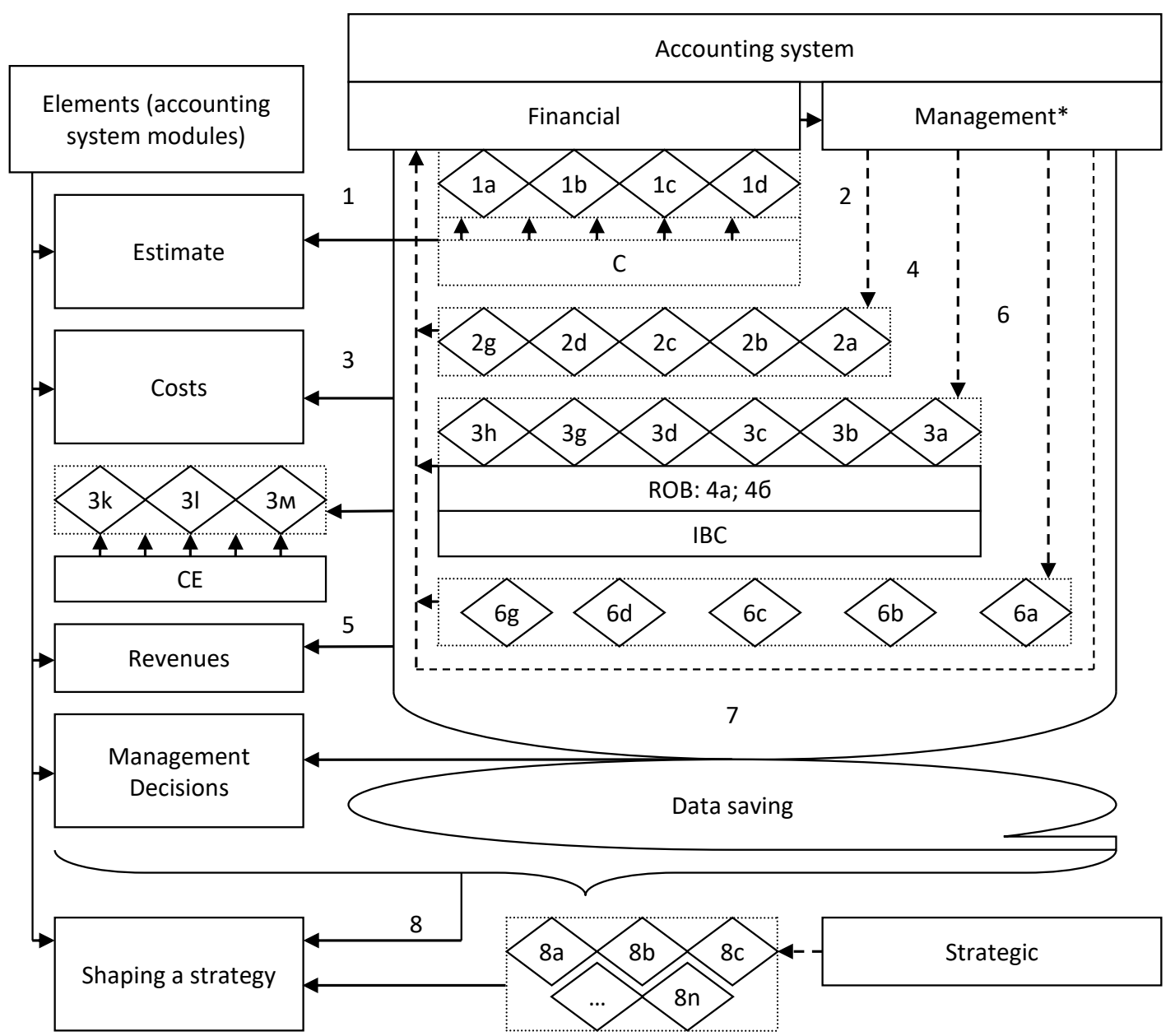

Notes: ${ }^{*}$ - recommended for the implementation in budgetary institutions; $\mathrm{C}$ - control (bodies of Treasury and other controlling authorities under the current legislation); 1 - the formation of a draft estimate in the financial accounting system; 2 - the formation of alternative projects of estimates to monitor opportunities to optimize costs; $1 \mathrm{a}$ - estimate calculation; $1 \mathrm{~b}-$ estimate coordination; $1 \mathrm{c}$ - approving of the estimate; $1 \mathrm{~d}$ - receiving the limit certificate and the accounting of financial support (documentary and in the system of accounts); $2 \mathrm{a}$ - accounting of performance indicators (including the basic (those used to calculate the amount of expenditures: general (network, area, volume, contingent) and specific (average annual number of students, pupils, beds, etc.) and their monitoring; $2 \mathrm{~b}$ - analysis of opportunities for improving the performance indicators calculation; $2 c$ - shaping the alternative projects of estimates based on improved indicators with substantiated of opportunities for decreasing costs; $2 \mathrm{~d}$ - approval of the management decision on choosing estimate's variant at the budgetary institution level; $2 \mathrm{~g}$ - final version of the optimized estimate with notes (the substantiation of the amounts of cost optimization is submitted in the notes); 3 - synthetic and analytical accounting of actual and cash expenditures under the current legislation; ROB - resultoriented budgeting; 4 - accounting of costs depending on the chosen method (given the method of accounting of costs in the system of management accounting); $3 \mathrm{a}$ - costs classification development; $3 \mathrm{~b}$ - costs valuation and planned budgets formation; $3 \mathrm{c}$ - calculation of prime cost of services (shaping the planned calculations); $3 \mathrm{~d}$ - verifying and developing a working plan of chart of management accounting accounts (it is proposed to form office accounts for costs accounting, revenues and financial results of budget performance); $3 \mathrm{~g}$ - cost accounting data preparation (according to the elements or items of expenditure, centers of responsibility, etc. depending on needs and specificity of entity business activity); $3 g-$ shaping internal reports about the revenues (depending on income types); $3 \mathrm{~h}$ - the use of analytical methods for results assessment (control and plan-fact analysis, break-even analysis and analysis of efficiency (the use of funds and capacity)); $3 \mathrm{k}$ - accounting of cash and actual expenditures; 31 - actual calculation of services; $3 \mathrm{~m}$ - aggregated data on expenditures (memorial warrants, log-main, etc.); $4 \mathrm{a}$ - basic budgets (budget of revenues and expenditures, cash flow budget), $4 \mathrm{~b}$ - functional budgets (budget of services' implementation, budget of direct costs, budget of administrative expenses, budget of general authorized costs); CE - control over expenditures by the Treasury; IBC - internal business control of costs (the use of LSIM, etc.); 5 - synthetic and analytical accounting of income under the current legislation; 6 - management accounting of revenues; $6 \mathrm{a}$ - classification of revenue for management purposes; $6 \mathrm{~b}$ - the development of structure and the list of accounts of revenues management accounting; $6 \mathrm{c}-$ the formation of accounting nomenclature; $6 \mathrm{~d}$ - the use of analytical methods (identifying opportunities to increase revenues); $6 \mathrm{~g}$ - internal accounting about the revenues of budgetary institution; 7 - generated information needed for making optimization management decisions regarding basic accounting objects (cash, expenses, revenues); 8 - the formation and analysis of information for making management decisions; $8 \mathrm{a}, 8 \mathrm{~b}, \ldots 8 \mathrm{n}$ - selected by the management priorities regarding information.

Figure 3. The general scheme of modules interconnection of accounting system in budgetary institutions 
ment decision-making; strategic management accounting), because there is a close relationship between them and chart of accounts, which is positioned as a "cause-effect" from a philosophical point of view (Figure 3).

Interconnections and components of financial and management accounting depicted in Figure 3 provide data preparation for management decision making of internal systemic nature. Subsequently, through theoretical substantiation of the developed modules it will be possible to form the concept about the composition of accounts in management accounting. The inclusion of formation of strategy of budgetary institution's activity into the list of modules requires considering and recording external information (information about the external environment). For this purpose, a system of strategic accounting was singled out due to the fact that according to traditional national approach, management accounting is considered to be an internal economic accounting. While according to semantic meaning of the word "management", it can be regarded in a much broader sense. In this case, the "Strategy formation" module could be attributed to management accounting.

\section{FUTURE RESEARCH OPPORTUNITIES}

In general, the subject is not fully investigated and is controversial, and therefore it can serve as the basis for further relevant studies and the formulation of the modern concept of the possibility to implement strategic accounting into the budgetary institutions' practice.

\section{DISCUSSION}

Functioning of budgetary institutions in market conditions requires an adequate accounting pro- viding for management of all processes taking place there. The main purpose is the widespread introduction of innovative approaches to accounting tools and its skillful use for achieving high positive results - effectiveness and adequate quality of services for budget institutions. Literature review points to the growing interest of scientists and practitioners to such issues and to certain developments on them.

Rational division of powers between the business entities of accounting and Chart of accounts belongs to the part of such tools according to the strategy of accounting modernization in the public sector. They are emphasized not only due to their role in the resource management at budgetary institutions, but also because of a number of gaps and problems on these issues regarding a distribution of powers between public sector entities, including administrators of budgetary funds and higher institutions, bodies and organizations and powers related to the accounting of assets, liabilities, income and expenses in the same budgetary institutions.

First, it is advisable to give more detailed definitions and a list of accounting entities in normative documents. In particular, entities defined by the Commercial Code as well as state and local government bodies and budgetary institutions should be included in their structure.

Second, it is appropriate to improve the accounting system of budgetary institution making management accounting subsystem its component. Given this, recommendations as to expanding the competence limits and functional responsibilities, which include accounting, planning and analysis, are proposed to develop. As a result of using this approach, specifications regarding the distribution of powers are formed and semantics of forming information in the budgetary institutions accounting system is defined.

\section{CONCLUSION}

The expediency of the specifying the Chart of accounts and introducing it to the part of accounts of management accounting based on the formed author's position regarding the building general scheme for module relationship to improve the system of accounting budgetary institutions has been substantiated. 
General scheme for interconnection of modules of the budgetary institutions' accounting system is built on the aforesaid grounds. The scheme covers the main elements of the module (estimate, income and expenses) and illustrates the areas of flow movement of accounting information in the subsystems of financial and management accounting.

The use of a reasonable strategic accounting methodology, a system that will help create a strategy for the functioning of budgetary institutions in the long run, will be justified for the full use of accounting information for optimization and efficiency improvement.

\section{REFERENCES}

1. Accounting Standards for the Public Sector (2017). Retrieved from http://www.minfin.gov.ua/ document/81046/B4.pdf (accessed on 28 November 2017).

2. Bergel, P. (2010). Rechnungshöfe als vierte Staatsgewalt? Universitätsdrucke Göttingen, Göttingen.

3. Bezzubets, L. L. (2012). Удосконалення та модернізація організації обліку в бюджетних установах [Udoskonalennia ta modernizaciia orghanizacii obliku v biudzhetnykh ustanovakh]. Retrieved from https://cyberleninka.ru/article/v/udoskonalennyata-modernizatsiya-organizatsiyiobliku-v-byudzhetnih-ustanovah

4. Cabinet of Ministers of Ukraine (2007). On Approval of the Strategy for the Modernization of the Accounting System in the Public Sector for 2007-2015. Retrieved from http://www.minfin. gov.ua/control/uk/publish/article/main?art_id (accessed on 4 December 2017).

5. Cabinet of Ministers of Ukraine (2011). On Approval of the Standard Provision on the Accounting Service of a Budgetary Institution. Retrieved from http:// zakon3.rada.gov.ua/laws/show/592011-\%D0\%BF (accessed on 8 December 2017).

6. Decker, R. (2012). Das staatliche Haushalts-, Kassen- und Rechnungswesen: Ein Grundriss für die öffentliche Verwaltung in Bund und Ländern [Broschiert], München, Landsberg, Frechen, Hamburg: Belz Druckpartner GmbH\&Cj.KG, Hemsbach.
7. Gizatulin, M. B. (2013). Accounting policy and its impact on information quality in accounting systems of public sector. Independent auditor, 5(3), 49-54.

8. Herasymenko, S. S., Yepifanov, A. O., Korinko, M. D. et al. (2010). Бухгалтерський облік: актуальні проблеми та рішення [Bukhghaltersjkyi oblik: aktualni problemy ta rishennia]. Sumy: SHEI "UAB NBU".

9. Horvath, P. (2003). Das Controllingkonzept. Der Weg zu einem wirkungsvollen Controllingsystem. München: Autor Statement: von Horvath \& Partners, Dt. Taschenbuch-Verb.

10. Hutsailiuk, Z. (2013). Облік і контроль у ринковій економіці: елементи концепції [Oblik i kontrol u rynkovii ekonomitsi: elementy koncepcii]. Ternopil: Krok.

11. Jamaludin, N., Lode, N., Ahmad, J., Abidin, A., Ali, A., \& Aziz, N. (2009). Fundamentals of Accounting and Finance, Meteor Doc. Sdn. Bhd.

12. Lysiak, L., Kachula, S., \& Kulichenko, V. (2017). Ukraine-EU cooperation for realization of innovative projects and programs aimed at public financial management modernization. Problems and Perspectives in Management, 15(2-1), 212-221. http://dx.doi. org/10.21511/ppm.15(2-1).2017.05

13. Makarenko, I. \& Plastun A. (2017). The role of accounting in sustainable development. Accounting and Financial Control, 1(2), 4-12.

14. Makarenko, I. (2017). Public companies non-financial reporting and audit in Ukraine: challenges and prospects. Accounting and Financial Control, 1(1), 32-38. https://doi. org/10.25161/afc.1(1).2017.04

15. Ministry of Finance of Ukraine (MFU) (2010). On approval of national regulations (standards) of accounting in the public sector. Retrieved from http://zakon. rada.gov.ua/cgi-bin/laws/main. cgi?nreg=z1017-10 (accessed on 4 November 2017).

16. Ministry of Labor and Social Policy (MLSP) (2004). On Approval of Issue 1 "Professions of workers that are common to all types of economic activity" of the Directory of qualification characteristics of the professions of workers. Retrieved from http://www.uazakon.com/ big/text15/pg1.htm (accessed on 21 November 2017)

17. Naboyshchikova, T. Yu. (2009). Учетная политика для целей управленческого учета в бюджетных учреждениях [Uchetnaya politika dlia tseley upravlencheskogo ucheta v biudzhetnykh uchrezhdeniyakh]. Bulletin of Volgograd State University. Series: the economy, 1(14), 158-162.

18. Paliy, V. F. (1975). Бухгалтерский учет в системе экономической информации [Bukhgalterskiy uchet v sisteme ekonomicheskoy informatsii]. Moscow: Finance.

19. Yevdokymov, V. V. (2005). Моделювання системи бухгалтерського обліку: теорія і практика застосування [Modeliuvannia systemy bukhghalterskoho obliku: teoriia i praktyka zastosuvannia]. Ph. D. thesis, State Academy of Statistics, Accounting and Auditing of the State Statistics Committee of Ukraine, Kyiv. 